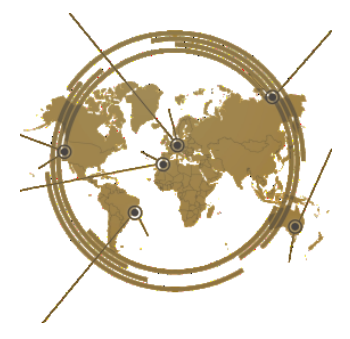

\title{
Developing e-learning media in grammar instruction for beginner learners
}

\author{
Nurul Afidah*, Hanifah, Dliyauddin Alkhoyyath \\ Universitas KH.A Wahab Hasbullah
}

The present study intended to develop E-learning media in teaching grammar for beginner learners. In developing the product, this study adapted the ADDIE model. The product that was developed using construct application focused on part of speech material. Thirty students of sixth grade enrolled on the implementation phase. Before implemented the product, some experts gave some suggestions and critics related to the quality of the product. The final product consists of some explanations of part of speech along with exercises, and in each exercise it is provided direct feedback whether the answer is right or wrong. On the first slide, a cover is displayed with attractive and colorful background since the target learner is beginner. The language used in this product is fully in English to habituate the learners with English environment. For the back sound, the researcher used rhythm only, not a song to avoid disturbing the learners. The researcher provides learning objectives. In this case there are three learning objectives. Then on the next slide it is showed eight part of speech that will be explained in detail. In material the researcher provided the definition and kinds of part of speech, also the example of part of speech. Moreover, the exercises were created in various types, ten questions in multiple choice and five questions in jumble word. This media can be used by anyone who needs it, and another researcher can develop similar media in different topic or level.

Keywords: technology, part of speech, ADDIE, young learners

OPEN ACCESS

ISSN 25033492 (online)

${ }^{*}$ Correspondence: Nurul Afidah

nurulafidah@unwaha.ac.id Received: 31th March 2020 Accepted: 30th March 2021 Published: 23th April 2021

Citation:

Afidah, Hanifah, and Alkhoyyath. (2021). Developing e-Learning Media in Grammar Instruction for Beginner Learners.

J. Eng. Educ. Society. 6:1. doi: 10.21070/jees.v6i1.363

\section{INTRODUCTION}

Nowadays, students live in a technological world. They use it all the time on their daily lives both at home or school. Also, some learning media that are conventional now move to digital Technology. As a teacher, we are demanded to be familiar with technology in education field. Grinager (2006) defined education technology as the use of hardware, software or other digital technologies in learning teaching process. The following is a partial list of the types of technologies found in educational settings. a) Computers or laptop b) Instructional Software and Digital/Online Content, c) Student Information Systems and Data Warehouses, d) Interactive Whiteboards and LCD Projectors, e) Sound Enhancement such as Speakers and microphones , f) Smart Cards, g) Televisions , h) Telephones, and i) Digital Cameras. Moreover, in this era using chalk and conventional method is not quite effective in English instruction. The teacher should be more creative in designing or using another teaching media such as technology (Susikaran, 2013). 
Technology can be utilized in many ways in language learning. Warschauer (2000) explained that there are two different views about how to integrate technology into the class. The first way is cognitive approach. In this approach, students are given opportunity to improve their exposure to language meaningfully and promote their own knowledge using any technology. In this case, common technology that is usually applied is applications of mobile learning that are easy to copy or install. The teacher may utilize it during class instruction both in delivering the material or giving exercises to the students. The second is the social approach. In this approach students get opportunities to have social interactions so that they can practice their skills in real life. Some technologies that can be used in this approach is application that provides direct communication among the users. In another way, the teacher can ask the student to record their activity when they have conversation with foreigner then upload the recording.

There are many kinds of tools that can be used in English instruction, and each tool has different benefits on each skill. Davies and Hewer (2012) said that when the teacher utilized used technology in language teaching, the computer will plays its role. However, the teacher should be familiar with computer or internet, and be able to utilize them during learning process. So that it is one of teacher role to habituate himself and the students using technology in English Instruction. It is in line with Nomass (2013) statement, "English language teachers should encourage their students to use technology in developing the language skills." Moreover, technology has several positive effects in language learning, but it will be more has beneficial result if it is combined with the role of teacher (Sharma, 2009). In addition Harmer (2007) and Gençlter (2015) declared that the learners should be encouraged to find appropriate activities using computer Technology so that they can be successful in learning process. Ahmadi (2018) said that technology enables interaction between students and teachers, supports the students to increase thinking skills, improves students' motivation in acquiring a foreign language, increases students' autonomy and confident, makes the atmosphere be more student-centered, and provides comprehensible input and output.

Several studies have shown that there are some benefits on the use of technology in classroom instruction. By using technology, it can increase student cooperativeness in creating projects. Cooperation or collaboration is very effective in instruction (Keser, Huseyin, \& Ozdamli, 2011). Also, they can learn each other from their peers who have higher ability. Moreover, technology can be used to create new environment, or to be used as problem solving in classroom instruction (Kurt, 2010). It is in line with previous statements, Siswandi (2017) revealed that ICTs have some positive effects on the EFL learners in the language teaching and learning. They felt more successful when using computer-based instruction. Also, they were more motivated to learn and their self-confidence and self esteem significantly increased. This was particularly true that by using the technology, it allowed learners to control their own learning. Moreover, Solanki and Shyamlee (2012) stated that there are some benefits of multimedia technology in English instruction. First, it improves students' interest and students' communication capacity, and interaction between teacher and student during instruction. Next, it can widen students' knowledge and creates a new context for Language teaching. Also, it gains an Insightful understanding to Western culture. Last, it can improve teaching effect and provide flexibility to course content. Also, Harmer (2007) and Gillespie (2006) stated that using computer-based language activities improve cooperative learning in learners. It is in line with Keser's statement. Keser and Ozdamli (2011) stated that Technology can improve cooperativeness among learners.

Mittal (2015) revealed the use of technology on language learning is necessary because of some reasons. First, technology gives them opportunity to see visual and audio aid and enhance communication skills. Second, the use of ICT and multimedia increase students' knowledge and give them some background knowledge in classroom study. Next, multimedia enriches teaching content, and there are many apps which offer the teacher to interact with students one-toone at any time even when they do not meet face to face. Forth, technology always makes class become interesting and interactive. Also, since ICT offers sound and picture coming together, students can use these things in the absence of teacher and revise the content for better understanding. Last, language teaching is not a one day process. It is a continuous process and needs special attention and revisions. So, teachers can give tasks to students and they can see their contents with the help of devices as per their need. Students can use technology, contact their teachers through Net when they are not in class and get their expert. Moreover, Christen (2009) stated that the students will be more excited if technology is utilized during class instruction. It is appropriate with young learners characteristics that need object than spoken word only (Wendy \& Lisbeth, 1990)

In this decade, there were some researchers who had conducted studies on the role of ICT in English instruction. Parvin and Salam (2015) investigated the effect of information and communication technology in English instruction in one of primary schools in Bangladesh. Based on the finding of the study, the researcher implied that the use ICT is very essential as learning media. The results of the study showed that the use of ICT has strong potential for enhancing and promoting interactive language classes. Teachers in the project claimed that the utilized of technology was highly beneficial, both to promote students' general language skill and to help students in learning the kind of English communication and language skills.

In another study, Solanki and Shyamlee (2012) investigated the use of multimedia technology in language teaching. Based on the finding of the study, it is stated that technology increases student learning motivation since it implicates students in the practical processes of language learning via communication with each other. The researchers recommended the teacher to use multimedia technology during class instruction since it has abundant positive impact. 
The finding of the research confirms that learners are more enthusiastic and interactive when they are using modern technology to assimilate English. Statistical data also shows that the students prefer to use modern media such as smart boards, computers and screens, than traditional teaching methods. Moreover, the study reveals that the interaction with teachers and overall responsiveness of students in the classroom is significantly increased when using modern techniques in English teaching.

Also, Baytak, Tarman, and Ayas (2011) investigated the effect of technology on learning process. The results showed that the teaching and learning process were more interactive and interesting when technology was incorporated into their classes. Moreover, students' social interactions, motivation, and engagement improved as well. Peregoy and Boyle (2012) used technology to improve students' reading and writing skill. After conducting the study, the finding indicated that it enhanced their skill both writing and reading. When technology was applied in class instruction, they could learn faster than traditional teaching method was used, also the teaching process was more effective. In addition, Godzicki et.al (2013) examined the effect of technology on motivation and engagement in English teaching process. Based on the finding it was revealed that when the teacher used technology as teaching media inside the class, students' engagement and motivation improved significantly.

Moreover, Vahdat and Behbahani (2013) investigated the effect of video games as teaching media on vocabulary learning. There were 40 intermediate EFL learners, both male and female who participated in this study. The finding of the study revealed that using video games has some benefits in vocabulary instruction. Also, males are more interested toward the use of video-game in vocabulary instruction than females.

Based on those previous studies, it had been clear that technology or ICT can be applied in any English skill and any level. Also, the teacher could utilize it in warming up activity, main activity, or in assessment process. It was depend on teacher need. Afidah and Ma'arif (2017) improved student score in grammar ability using ICT based instruction. It was optimally applied during main activity. The media being applied was video that was designed by using Video Subscriber Application.

On the present study, interviewing the English teacher was conducted on need analysis phase to get initial information related to the existing media, and it was obtained that the teacher only used worksheet in part of speech material, and the exercises were taken from that worksheet. The teacher did not use another media. Moreover, the researcher also interviewed the students, and it showed that both the teacher and students need interactive e-learning media as the supplementary media in grammar instruction. Based on the reasons above, the researcher intended to develop e-learning media in grammar instruction for elementary school students by using construct application.

\section{METHODS}

In this study, product being developed is e-learning media in grammar instruction using construct application. It means that this study uses research and development design that is well known as R n D. Research and development is a research which aims producing or creating new educational procedures or product (Richey \& Klein, 2007).

Some models of research and development had been developed by several experts (Dick, 1996; Thiagarajan, 1974). This research belongs to Research and Development, and ADDIE model is chose since it is the feasible model to adapt. This model covers analyze, design, develop, implement, and evaluate (ADDIE).

The first step is analysis. In this step the researcher interviewed the teacher and students whether they needed the media based ICT for their English instruction. The next step is design. In this step the researcher designed the media by using construct 2 . Before designed it, the researcher drew the rough draft related to part of speech for elementary school. The next step is developing. After designing the products for several months, the researcher consults the product to the experts to get suggestions and critics related to the feasibility of the product. The fourth step is implementation. The researcher implemented or tried out the product on sixth grade students, and the researcher used questionnaire to obtain some suggestions from the user. The last step is evaluation. In this part the researcher evaluated the product based on the suggestion from the experts and the users.

Here is the description of product being developer. The first slide a cover is displayed with attractive and colourful background since the target learner is beginner. The definition of beginner in this study is sixth grade of elementary school students, but another beginner learner may also use this product. The language used in this product is fully in English to habituate the learners with English environment. For the back sound, the researcher used rhythm only, not a song to avoid disturbing the learners. After cover, the researcher provides learning objectives. In this case there are three learning objectives: a) the students are able to identify the meaning of eight parts of speech, b) the students are able to identify kinds of each part of speech, c) the students are able to identify the example of eight part of speeches.

Then on the next slide it is showed eight parts of speech that will be explained in detail. Those are noun, verb, adjective, adverb, pronoun, preposition, conjunction, and interjection. Each part of speech is completed by material and exercises as well. In material the researcher provided the definition of part of speech, kinds of part of speech, also the example of part of speech. Along with the explanation, it is also provided visual aids to help the student. After explanation, the students are asked to have to exercises. The exercises are created in various types. Those were ten questions in multiple choice and five questions in jumble word. 
Some instruments used in this study were interview sheet, questionnaire and Validation sheet. Those instruments were constructed by the researcher. Interview was used to obtain the data from the teacher and the students related their need on learning media. Validation sheet was used to get the data from the experts in developing phase, questionnaire was used to get some information regarding their perception after using the product.

\section{RESULTS AND DISCUSSION}

On analyze phase, the researcher interviewed the teacher and students whether they needed the media based ICT for English instruction. The interview was conducted before the product was developed. The blueprint of interview sheet covered twelve questions related to the media used on English instruction in that class. From the result of interview, it was obtained data that both students and teacher needed supplementary materials in grammar instruction especially in part of speech material.

Next, the researcher drew the general concepts of the product. Some components being prepared were the material of part of speech and the exercises as well. In this phase the researcher was helped by ICT expert to design the product, so the researcher only provided the outline and the content. Construct 2 application was utilized to design the media. Construct 2 was one of platforms android that could be used in creating game.

After designed the product, the researcher involves material expert and media expert to give suggestion and criticize the quality of the product. In develop phase, validation sheet is utilized to obtain suggestions and critics from the expert. The suggestions and critics are used as the basis in revising the product.

In design phase, the researcher involved two validators. The first validator is one lecture of Wahab Hasbullah University who taught in Faculty of Education. The researcher chose him because of his expertise in learning media development. Moreover, he had developed several media in different types during these years. The next validator was one of lectures in Wahab Hasbullah University who had taught in Faculty of Information Technology more than 5 years. Based on the result of validation sheet and questionnaire given to the students, there were some critics and suggestions such as : a) it is better to add another variation of exercises, b) Change the background colour and backsound that is more attractive, $d$ ) There were some grammatical errors on the product, and e) add back button. The following were data obtain during design phase both from media validator and material validator.

TABLE $1 \mid$ Data Obtained from Media Validator

\begin{tabular}{lllc}
\hline No & Content & \multicolumn{1}{c}{ Criteria } & Score \\
\hline 1 & Letter & $\begin{array}{l}\text { The use of letter is } \\
\text { appropriate, clear, and } \\
\text { readable. }\end{array}$ & 4 \\
2 & Typing & $\begin{array}{l}\text { The typing is clear, neat, } \\
\text { and regular. }\end{array}$ & 3
\end{tabular}

\begin{tabular}{|c|c|c|c|}
\hline 3 & Spacing & $\begin{array}{l}\text { The spacing is appropriate } \\
\text { and consistent. }\end{array}$ & 4 \\
\hline 4 & Lay Out & $\begin{array}{l}\text { The layout is attractive and } \\
\text { clear. }\end{array}$ & 3 \\
\hline 5 & $\begin{array}{l}\text { Operating } \\
\text { System }\end{array}$ & $\begin{array}{l}\text { The product is easy to } \\
\text { operate. }\end{array}$ & 4 \\
\hline 6 & $\begin{array}{l}\text { Scoring } \\
\text { System }\end{array}$ & $\begin{array}{l}\text { Scoring system is fair and } \\
\text { well regulated. }\end{array}$ & 4 \\
\hline 7 & Button & $\begin{array}{l}\text { The click-buttons can be } \\
\text { operated }\end{array}$ & 4 \\
\hline 8 & Time & $\begin{array}{l}\text { The time of answering is } \\
\text { adequate. }\end{array}$ & 3 \\
\hline 9 & Color & $\begin{array}{l}\text { The color in the product is } \\
\text { appropriate. }\end{array}$ & 4 \\
\hline \multirow{3}{*}{$\begin{array}{l}10 \\
11\end{array}$} & Music & The music is appropriate & 4 \\
\hline & Image & $\begin{array}{l}\text { The selection of the images } \\
\text { is appropriate. }\end{array}$ & 3 \\
\hline & & Total Score & 40 \\
\hline
\end{tabular}

Table 2 presented the data that was obtained from validation sheet of Material validator. The total score was 23 which can be described that the media was very good and deserved to implement.

TABLE $2 \mid$ Data Obtained from Material Validator

\begin{tabular}{|c|c|c|c|}
\hline No & Component & Criteria & $X i$ \\
\hline 1 & $\begin{array}{l}\text { Organization } \\
\text { of the } \\
\text { materials }\end{array}$ & $\begin{array}{l}\text { The organization of the } \\
\text { materials and activities is } \\
\text { appropriate. }\end{array}$ & 3 \\
\hline 2 & Vocabulary & $\begin{array}{l}\text { The selection of the vocabulary } \\
\text { is appropriate to the target } \\
\text { situation. }\end{array}$ & 3 \\
\hline 3 & Grammar & $\begin{array}{l}\text { The grammar is correct and } \\
\text { accurate. }\end{array}$ & 3 \\
\hline 4 & Presentation & $\begin{array}{l}\text { Presentation is clear, educative, } \\
\text { and constructive. }\end{array}$ & 3 \\
\hline 5 & Objective & $\begin{array}{l}\text { The product can motivate } \\
\text { students. }\end{array}$ & 3 \\
\hline 6 & $\begin{array}{l}\text { Scoring } \\
\text { System }\end{array}$ & $\begin{array}{l}\text { Scoring system is fair and well } \\
\text { regulated. }\end{array}$ & 2 \\
\hline \multirow[t]{2}{*}{7} & $\begin{array}{l}\text { Level of } \\
\text { Difficulty }\end{array}$ & $\begin{array}{l}\text { The level of difficulty of each } \\
\text { question is proper with the } \\
\text { score. }\end{array}$ & 3 \\
\hline & & Total Score & 20 \\
\hline
\end{tabular}

In implementation phase the researcher applied the product during two meetings. The topics discussed were only noun and verb. The number of students who enrolled in the try out or implementation phase is thirty students of sixth grade MI KEBOKICAK JOMBANG. 18 of them are male, and 12 of them are female. Most of them had learnt English since on the third grade. It means that they had learnt English mostly for three years.

After implemented the product, students were given questionnaire to get their response related the feasibility of the product. The questionnaire consisted of twelve questions that covered whether the letter was clear, whether the colour and picture was interesting, whether the explanation was 
easy to understand, and so for. The following are the data obtained in this stage.

TABLE 3 | The Result of Questionnaire for Users

\begin{tabular}{|c|c|c|c|c|c|}
\hline No & Statements & $\begin{array}{c}\text { Totally } \\
\text { agree }\end{array}$ & Agree & disagree & $\begin{array}{l}\text { Totally } \\
\text { disagree }\end{array}$ \\
\hline 1 & The design of this application is attractive & $70 \%$ & $23.33 \%$ & $3.33 \%$ & $3.33 \%$ \\
\hline 2 & The font letter is readable & $80 \%$ & $20 \%$ & - & - \\
\hline 3 & The background is eye catching & $86.67 \%$ & $10 \%$ & $3.33 \%$ & - \\
\hline 4 & $\begin{array}{l}\text { The backsound does not disturb me in learning part of } \\
\text { speech }\end{array}$ & $80 \%$ & $16.67 \%$ & $3.33 \%$ & - \\
\hline 5 & The picture helps me comprehending the material & $66.67 \%$ & $20 \%$ & $10 \%$ & $3.33 \%$ \\
\hline 6 & The button is easy to operate & $80 \%$ & $16.67 \%$ & $3.33 \%$ & - \\
\hline 7 & The explanation is easy to understand & $66.67 \%$ & $23.33 \%$ & $6.67 \%$ & $3.33 \%$ \\
\hline 8 & The exercise is not too difficult & $63.33 \%$ & $20 \%$ & $10 \%$ & $6.67 \%$ \\
\hline 9 & The instruction in each exercise is easy to understand & $80 \%$ & $13.33 \%$ & $3.33 \%$ & $3.33 \%$ \\
\hline 10 & $\begin{array}{l}\text { All test items on the exercises have been explained on } \\
\text { the material }\end{array}$ & $83.33 \%$ & $10 \%$ & $6.67 \%$ & $3.33 \%$ \\
\hline 11 & $\begin{array}{l}\text { The application motivates me to learn English } \\
\text { especially part of speech }\end{array}$ & $66.67 \%$ & $30 \%$ & $3.33 \%$ & - \\
\hline 12 & I like to use this application in grammar class & $73.33 \%$ & $23.33 \%$ & $3.33 \%$ & - \\
\hline
\end{tabular}

From the data (Table 3 ) obtained from the questionnaire, it could be concluded that media developed was easy to operate especially for elementary school. Moreover, the background and back sound were appropriate to their age. The language used was easy to understand so that the students also could operate it autonomously. The exercises were also designed based on their level. Since they were beginner so the exercises provided were basic level. Overall, most of them were interested in using this application.

After being revised, the final product developed can be described as follow:

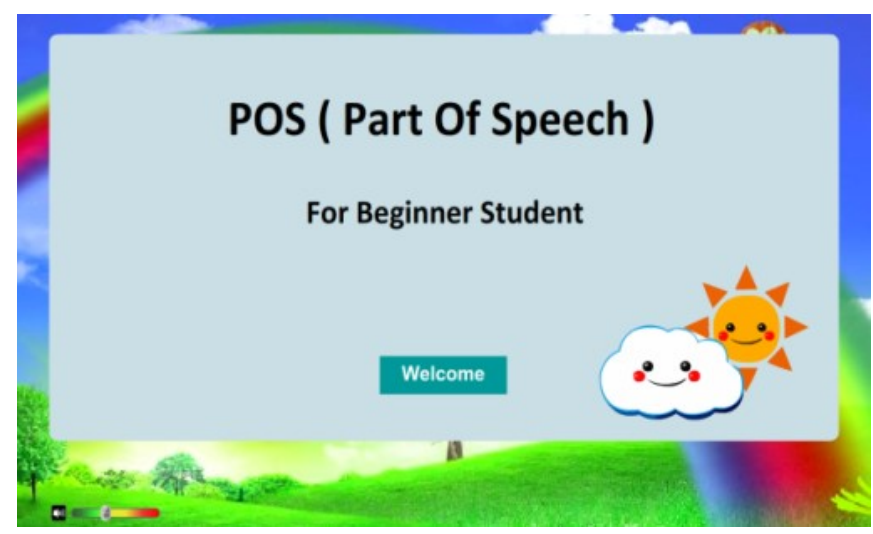

FIGURE 1 | Cover of Application

On the cover, the researcher only displayed POS (Part of Speech) for beginner students. The reason why the researcher used the term beginner since this application also could be used by another beginner learners who needed it. However the definition beginner in this study is students of sixth grade. When the user wants to start to learn, they can click the welcome button.

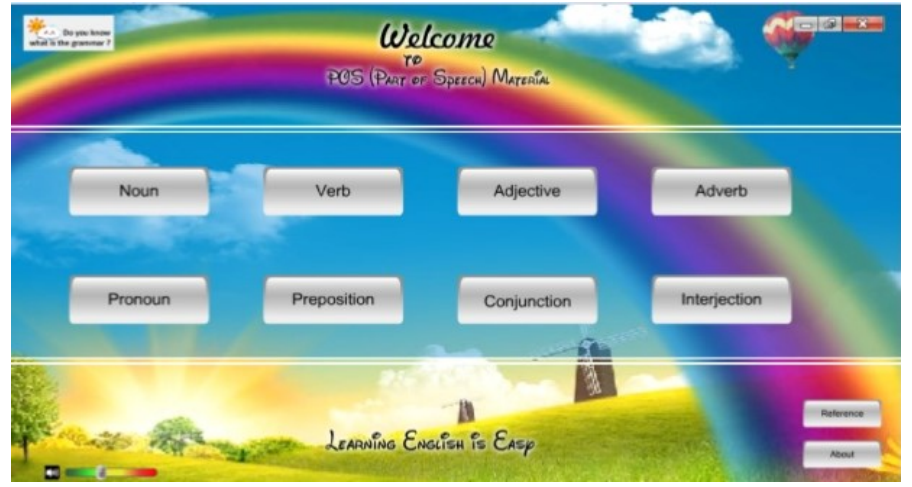

FIGURE 2 | Kinds of Part of Speech

After click welcome, the user will see kinds of part of speech. Before giving exercises, the researcher also gave material related part of speech. In this application there were eight parts of speech. Those were noun, verb, adjective, adverb, pronoun, preposition, conjunction, and interjection. When the user clicked one of part of speeches, there were three categories that involved in this slide. Those were the definition of part of speech, kinds of part of speech, and the exercises.

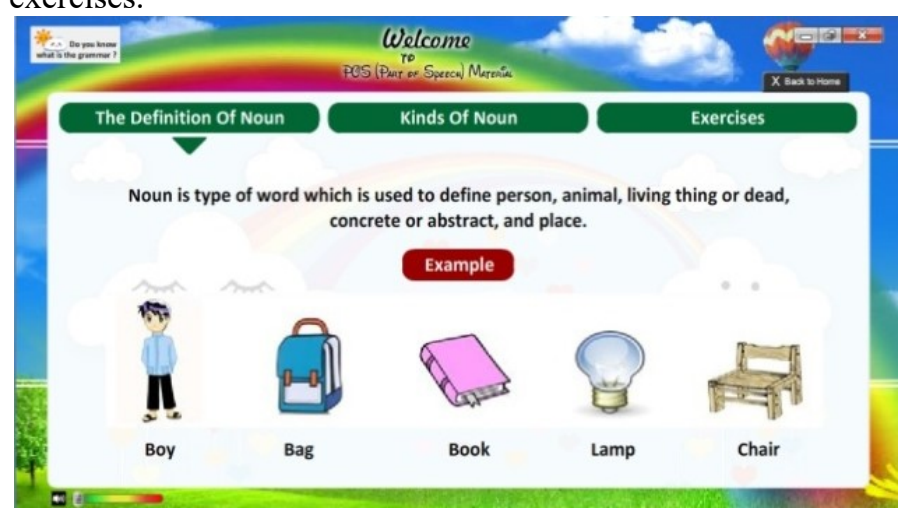

FIGURE 3 | The Definition of Part of Speech 
On the definition, the researcher defined the part of speech and gave some examples as well. Since the target user was beginner, so the researcher helped them by giving some pictures on the example. In this part the teacher also can add more examples using another media.

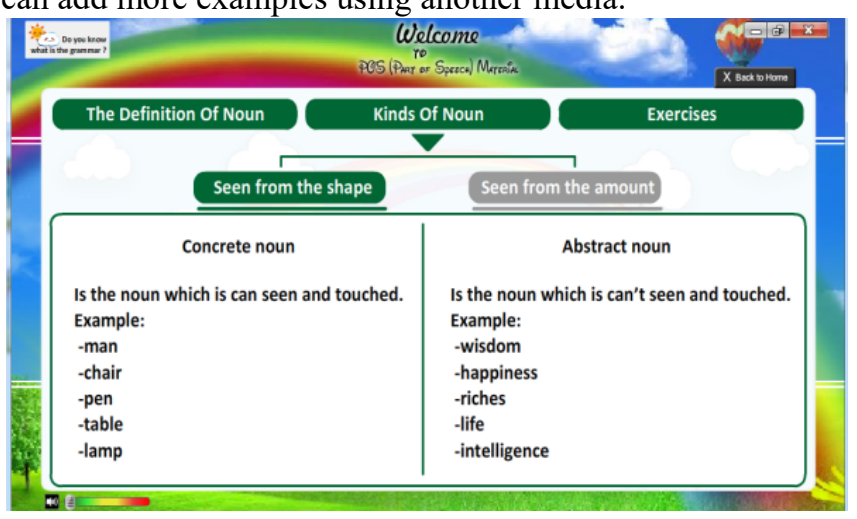

FIGURE 4 | More Explanation of Part of Speech

In this slide, the researcher explained more about kinds of part speech and the example. Different topic will have different the number of variety of part of speech.

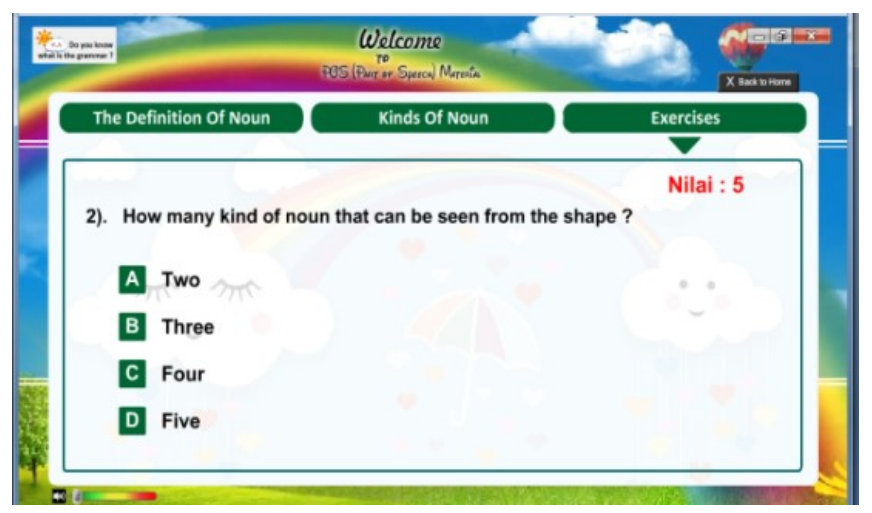

FIGURE 5 | Multiple Choice Exercises

Then, there were two kinds exercise given on the application. The first type was ten questions of multiple choices. The users got score five if they had right answer. However, they would get zero if they had wrong answer. The score appeared automatically on the above.

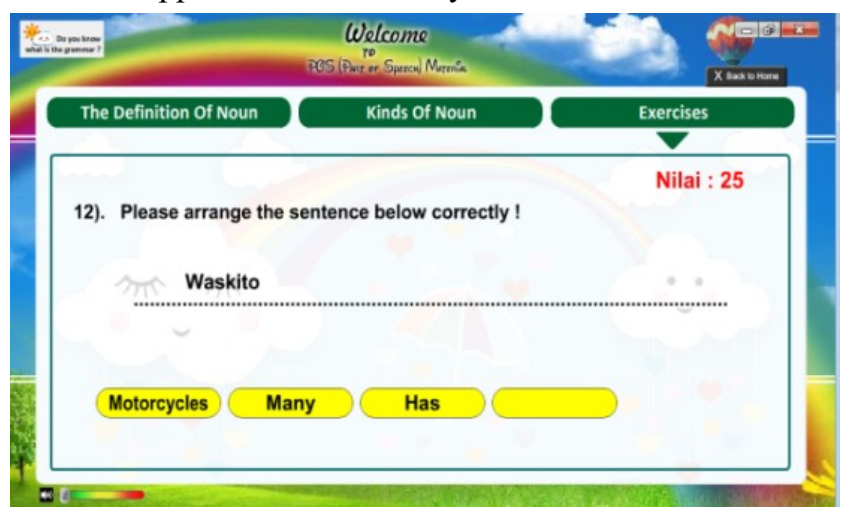

FIGURE 6 | Jumble Word Exercises

The next type on the exercise was jumbled word. There were five items of jumbled word. It was provided some words then the users should click the word to arrange into sentence that had complete thought. As like previous one, the users got score five if they had right answer. However, they would get zero if they had wrong answer. Something that were rather different was the users could not continue to the next number if they still had wrong arrangement.

This application can be copied and installed easily in any personal computer. It has owned the criteria of good media. As stated by Harmer (2000) that good learning media is media that is flexible and feasible. Also, the exercises provided feedback for the user. Every application, of course, has strength and weakness. The following are the strength of product developed: a) This application is easy to operate, b) This application is easy to install or copy, c) This application can be operated without internet connection, d) This application can be operated without teacher instruction. It is supported by Mittal (2015) who stated that the students can learn by themselves although there was no teacher beside them. e) This application provides automatic score, and f) All part of speech include in this product. Moreover, on implementation phase, the students were highly attracted toward the product. It seemed that they enjoy using product developed. It is in line with Christen (2009) who stated that the students will be more excited if technology is utilized during class instruction especially for young learner.

However the weaknesses of this product are the target learner of this product is beginner, so the exercises are too easy for intermediate or advance learner. Then this product can be operated using laptop or personal computer only.

\section{CONCLUSION}

As stated in background, this research is intended to develop e-learning media in grammar instruction for sixth grade of elementary school students since the media that was used by the teacher was only worksheet. Moreover, the students needed supplementary attractive media so that the researcher decided to develop this e-learning media. The topic explained on the product developed is part of speech. From the result of design phase and implementation phase, the media deserved to use in Grammar teaching and learning in MI Kebokicak Jombang.

This research is far from being perfect, the next researcher can design similar product in different topic or different level. Also, because this study used research and development design, further researchers can use another research design such as utilizing E-learning media to improve students' English achievement.

\section{ACKNOWLEDGMENT}

Thanks to everyone who had helped me finishing this study.

\section{REFERENCES}

Afidah, N., \& Ma'arif, I. (2017). Utilizing Magic Finger Method in Grammar Class. Journal of English Educators Society, 2 (1), 45-52. doi:http://dx.doi.org/10.21070/jees.v2i1.677 
Ahmadi, M., R. (2018). The Use of Technology in English Language Learning: Literatur Review. International Journal of Research in English Education. 3(2). 115125.

Akkoyunlua ,B \& Erkanb, S. ( 2013 ). A Study on student and teacher views on technology use. Procedia Social and Behavioral Sciences. 103.68-76.

Baytak, A., Tarman, B., \& Ayas, C. (2011). Experiencing Technology Integration in Education: Children's Perceptions. International Electronic Journal of Elementary Education, 3(2), 139-151. https://www.iejee.com/index.php/IEJEE/article/view/ 233. accessed on April 17, 2018.

Davies, G., \& Hewer, S. (2012). Introduction to New Technologies and how They Can Contribute to Language Learning and Teaching. Module 1.1 in Davies G. (ed.), Information and Communications Technology for Language Teachers (ICT4LT), Slough, Thames Valley University [Online]. Retrieved from http://www.ict4lt.org/en/en_mod11.htm on April 30, 2020.

Dick, W. (1996). The Dick and Carey model: Will it survive the decade?. Educational technology research and development, 44(3), 55-63.

Christen, A. (2009). Transforming the Classroom for Collaborative Learning in the 21st Century. Techniques: Connecting Education and Careers (J1), 84(1), 28-31.

Gillespie, H. (2006). Unlocking Learning and Teaching with ICT: Identifying and overcoming barriers. London: David Fulton.

https://trove.nla.gov.au/work/20064464 accessed on April 30, 2020.

Gençlter, B. (2015). How Does Technology Affect Language Learning Process at an Early Age? Procedia - Social and Behavioral Sciences, 199(2015), $311-316$. doi: 10.1016/j.sbspro.2015.07.552

Godzicki, L., Godzicki, N., Krofel, M., \& Michaels, R. (2013). Increasing Motivation and Engagement in Elementary and Middle School Students Through Technology-Supported Learning Environments. Retrieved from http://www.eric.ed.gov.ezproxy.cuportland.edu/conte ntdelivery/servlet/ERICServlet?accno $=$ ED541343 on April 30, 2020

Grinager, H. (2006) How Education Technology Leads to Improved Student Achievement, National Conference of State Legislatures.

Harmer, J. (2007). The practice of English Language Teaching. England: Pearson.

Keser, H. \& Ozdamli, F. (2011). The Trends in Technology Supported Collaborative Learning Studies in 21st Century. World Journal On Educational Technology, 3(2), 103-119.

Kurt, S. (2010). Technology use in elementary education in Turkey: A case study. New Horizons in Education, 58(1), 65-76.
Larsen- Freeman, D., \& Anderson, M. (2011). Techniques and Principles in Language Teaching. Oxford: OUP.

Mittal , R. ( 2015) Use of Technology in English Language Teaching: Is it Helping Students and Teachers?, Dak Degree College, India The Asian Conference on Arts \& Humanities . Official Conference Proceedings

Nomass , B. B.( 2013) The Impact of Using Technology in Teaching English as a Second Language English Language and Literature Studies; Vol. 3, No. 1;. Published by Canadian Center of Science and Education

Parvin, R. H., \& Salam, S. F. (2015). The Effectiveness of Using Technology in English Language Classrooms in Government Primary Schools in Bangladesh. FIRE: Forum for International Research in Education, 2(1). 47-59. http://dx.doi.org/10.18275/fire201502011049.

Peregoy, S., \& Boyle, O. (2012). Reading, Writing and Learning in ESL: A Resource Book for Teachers. New York: Allyn \& Bacon.

Richey, R. C., \& Klein, J. D. (2007). Design and development research. Mahwah, NJ.

Sharma, P. (2020,). Controversies in Using Technology in Language Teaching.

http://www.teachingenglish.org.uk/articles/controvers ies-using-technology-language-teaching . Retrieved at April 28, 2020.

Siswandi . (2017). Developing ICT Material to Enhance EFL Teachers Performance in ELT Classroom. IJIELT, Indonesian Journal Of Integrated English Langauge Teaching. 3 (1). 119-127.

Solanki D., \& Shyamlee, M Phil. (2012). Use of Technology in English Language Teaching and Learning": An Analysis. International Conference on Language, Medias and Culture. IPEDR vol.33. IACSIT Press, Singapore

Susikaran, R. S. A. (2013). The use of multimedia in English language teaching. Journal of Technology for ELT, $3(2)$.

Thiagarajan, S. (1974). Instructional development for training teachers of exceptional children: A sourcebook.

Vahdat \&, Behbahani, A., R.( 2013). The Effect of Video Games on Iranian EFL Learners' Vocabulary Learning. The Reading Matrix, 13(1).

Warschauer, M. (2000). The Death of Cyberspace and the Rebirth of CALL. English Teachers' Journal, 53, 61-67.

Wendy A Scott \& Lisbeth H Yterberg (1990) Teaching English to Children. New York: Longman. 
Conflict of Interest Statement: The authors declare that the research was conducted in the absence of any commercial or financial relationships that could be construed as a potential conflict of interest.

Copyright () 2021 Nurul Afidah, Hanifah, and Dliyauddin Alkhoyyath. This is an open-access article distributed under the terms of the Creative Commons Attribution License (CC BY). The use, distribution or reproduction in other forums is permitted, provided the original author(s) and the copyright owner(s) are credited and that the original publication in this journal is cited, in accordance with accepted academic prac- tice. No use, distribution or reproduction is permitted which does not comply with these terms. 